\title{
Prijevodne strategije u hrvatskim podslovima na primjeru talijanskog filma Smetto quando voglio
}

\author{
Andrea Rogošić \\ arogosic@ffst.hr \\ Filozofski fakultet Sveučilišta u Splitu \\ Petra Mrčela \\ pmrcela@gmail.com \\ Filozofski fakultet Sveučilišta u Splitu
}

Cilj je ovog rada kvantificirati i opisati prijevodne strategije primijenjene u podslovljavanju talijanskog filma Smetto quando voglio (2014) na hrvatski jezik. Zbog vremensko-prostornih ograničenja karakterističnih za tehniku podslovljavanja, kao i zbog dijamezijske transformacije govornog jezika u pisani, polazi se od pretpostavke da će strategije redukcije i neutralizacije predstavljati najčešće metode prilagodbe ciljnog teksta. Na temelju transkripcije izvornog teksta i hrvatskih podslova provodi se kvantitativna analiza prijevodnih strategija prema Lomheimovoj taksonomiji iz 1999. godine, a potom se kvalitativno analiziraju odabrani primjeri najučestalijih prijevodnih strategija, točnije ekvivalentnog prijevoda, izostavljanja, kompresije te neutralizacije. Zaključuje se da primjenom redukcijskih strategija nije narušena koherentnost ciljnog teksta, dok se primjenom neutralizacije u određenoj mjeri mijenja jezična karakterizacija filmskih protagonista.

Ključne riječi: hrvatski podslovi, redukcijske strategije, neutralizacija 


\section{UVOD}

Podslovljavanje kao oblik audiovizualnog prevođenja predstavlja relativno novo područje u okviru šire discipline znanosti o prevođenju. Dok svega nekoliko europskih zemalja koristi sinkronizaciju kao temeljni oblik audiovizualnog prevođenja, ostatak Europe, pa tako i Hrvatska, oslanja se prvenstveno na tehniku podslovljavanja. Razlog je tome činjenica da je podslovljavanje znatno manje zahtjevna i znatno jeftinija metoda audiovizualnog prevođenja.

Osim ekonomske isplativosti, očuvanje zvučnog zapisa na izvornom jeziku bitan je čimbenik velike rasprostranjenosti ove metode jer se na taj način podupire i unaprjeđuje proces učenja stranih jezika. Vjerojatno je upravo iz tog razloga primjetan sve veći interes za podslovljenim inačicama stranih filmova i serija čak i u zemljama poput Italije ili Španjolske, koje tradicionalno koriste sinkronizaciju kao dominantnu tehniku audiovizualnog prevođenja (Díaz Cintas, 2014: 298).

U skladu s navedenim, tijekom posljednja dva desetljeća uočava se neprekidan rast interesa znanstvenika za istraživanjem ove tehnike audiovizualnog prevođenja iz različitih aspekata. Međutim, unatoč tome što $\mathrm{Hr}$ vatska pripada bloku zemalja koje kao primarnu tehniku audiovizualnog prevođenja koriste podslovljavanje, ova je tematika imala slabijeg odjeka među hrvatskim jezikoslovcima u odnosu na druge europske zemlje. Posebice se to odnosi na podslovljavanje talijanskih audiovizualnih tekstova na hrvatski jezik, a koje do ovog trenutka gotovo da i nije bilo predmetom znanstvenih istraživanja.

Navedena je činjenica predstavljala jedan od motiva za izradu ove studije slučaja temeljene na kvantitativnoj analizi i opisu jezičnih strategija primijenjenih u podslovljavanju talijanskog filma Smetto quando voglio (2014) na hrvatski jezik. Film je odabran kao predmet studije slučaja zbog svoje kompleksnosti, koja se očituje u brzom ritmu govora te zgusnutim dijalozima, mnoštvu žargonizama, vulgarizma i dijalektizama, kao i zbog specifične uporabe brojnih neprilagođenih riječi iz engleskog jezika. Riječ je, dakle, o čimbenicima koji upućuju na neizbježnost primjene strategija poput izostavljanja, kompresije i neutralizacije u ciljnom tekstu.

\section{PODSLOVLJAVANJE: TEMELJNA OBILJEŽJA}

Gottlieb (2004: 220) definira podslovljavanje kao prijevod polisemiotičkih medija u obliku jednog ili više redaka pisanog teksta koji se pojavljuje na ekranu simultano s izvornim dijalogom. Analizirajući komponente audio- 
vizualnog teksta, Delabastita (1998: 199) razlikuje četiri komunikacijska kanala: verbalno-vizualni, neverbalno-vizualni, verbalno-akustični i neverbalno-akustični kanal. Značenje u audiovizualnom tekstu proizlazi iz sva četiri komunikacijska kanala, a razina ovisnosti podslova o svakom od njih je varijabilna i potrebno ju je odrediti za svaki podslov napose.

U tom smislu F. Chaume (2004a: 232-237) proširuje koncept kohezije teksta uvodeći pojam „semiotičke kohezije“, odnosno uključujući u postojeću definiciju vezu između jezičnog i vizualnog kanala. Drugim riječima, ono što je izostavljeno u podslovu može biti nadopunjeno informacijama koje su sadržane u vizualnoj komponenti.

Podslovljavanje može biti intralingvalno i predstavljati pisanu verziju izvornog dijaloga koja je namijenjena osobama oštećena sluha ili može biti interlingvalno, odnosno može predstavljati prijevod izvornog teksta na drugi jezik. I u jednom i u drugom obliku podslovljavanja dolazi do dijamezijske transformacije teksta, to jest do pretvaranja govornog oblika izvornog teksta u pisani oblik ciljnog teksta. Takva transformacija podrazumijeva izostavljanje određenih elemenata koji su karakteristični za govorni jezik, kao što su, primjerice, različite diskursne oznake, vulgarizmi ili dijatopijski obilježeni elementi. Međutim, reduciranje sadržaja nužno je također i zbog postojanja vrlo konkretnih tehničkih ograničenja kojima podslovi podliježu.

\subsection{Vremenska i prostorna ograničenja podslova}

Podslov se može sastojati od maksimalno dva retka teksta koji, u pravilu, sadržavaju do 37 znakova uključujući i prazna mjesta, što bi značilo da cjelokupan podslov može sveukupno sadržavati maksimalno 74 znaka. ${ }^{1}$ Vremensko ograničenje podslova temelji se na načelu da podslov mora biti sinkroniziran s izvornim dijalogom te da trajanje podslova na ekranu mora biti dovoljno dugo da ga prosječni čitatelj može pročitati, a istovremeno posvetiti pozornost i vizualnoj komponenti. To se prije svega odnosi na titlanje, odnosno precizno određivanje trenutka u kojem se podslov treba pojaviti na ekranu odnosno nestati s ekrana (eng. spotting). Što se pak tiče trajanja podslova na ekranu, tradicionalno se primjenjuje takozvano „pravilo šest sekundi“ (D’Ydewalle, Van Rensbergen i Pollet, 1987).

Na razini spomenutog ograničenja problem nastaje ukoliko se dijalozi izmjenjuju velikom brzinom pa primjena skraćivanja ili redukcije izvornog

\footnotetext{
${ }^{1}$ Broj znakova po retku podslova podložan je manjim varijacijama, od 33 do 40 znakova (Díaz Cintas i Remael, 2007: 84).
} 
teksta, koja može biti djelomična ili potpuna, postaje neizbježna. Djelomična redukcija postiže se kroz veću konciznost izraza na ciljnom jeziku, a potpuna redukcija podrazumijeva izostavljanje pojedinih leksičkih komponenti. U tom kontekstu Kovačič (1991: 409) u procesu podslovljavanja razlučuje tri vrste elemenata: 1 ) elementi koji su od primarne važnosti i moraju biti prevedeni; 2) elementi koji su od sekundarne važnosti pa ih je moguće reducirati i 3) elementi koji nisu važni i mogu biti izostavljeni. Drugim riječima, ako se procijeni da određeni elementi nisu bitni za razumijevanje teksta, a ekvivalentnim prijevodom nije moguće zadovoljiti načelo o ukupnom broju znakova i trajanju podslova na ekranu, potrebno je pristupiti njihovom reduciranju ili pak potpunom izostavljanju.

Stupanj redukcije u odnosu na izvorni tekst može ovisiti o, primjerice, filmskom žanru (Georgakopoulou, 2003), ali može varirati i unutar samog filma, ovisno o pojedinim prizorima. Različita istraživanja stupnja redukcije u podslovljavanju filmova iznjedrila su i različite rezultate koji se kreću u rasponu od 22 \% do 37 \% (Lomheim, 1995: 203). Prema Gottliebu (1992: 247) televizijsko podslovljavanje podrazumijeva prosječnu stopu redukcije teksta od $30 \%$.

Ne postoje konkretna pravila o tome što i u kojoj mjeri skratiti ili izostaviti jer se odluka donosi posebno za svaku pojedinu situaciju, vodeći računa o žanru odnosno o retoričkoj funkciji pojedinih elemenata u određenom kontekstu. Upravo iz tog razloga deskriptivan pristup, odnosno proučavanje i analiza postojećih podslova, predstavlja najbolji način definiranja dobre prakse u podslovljavanju (Díaz Cintas i Remael, 2007: 149).

\subsection{Podslov: prijevod ili adaptacija?}

Neka od do sada navedenih obilježja podslova neminovno dovode do pitanja je li uopće opravdano podslovljavanje nazivati prevođenjem. To je ujedno i jedan od razloga zašto je dugi niz godina audiovizualno prevođenje bilo zanemareno od strane znanstvenika koji su se bavili teorijom prevođenja (Díaz Cintas i Remael, 2007: 9). Iako Gottlieb (2004: 219) tvrdi da se svaki međujezični transfer s pravom naziva prevođenjem, činjenica je da tehnike koje se primjenjuju pri podslovljavanju previše udaljavaju podslove od klasične definicije prijevoda, odnosno da se tekst previše adaptira i mijenja kako bi se prilagodio tehničkim ograničenjima koja se tiču duljine i trajanja podslova na ekranu (Luyken i sur., 1991: 153). Iz tog razloga Gambier (2003: 178) kada govori o podslovljavanju upotrebljava termin „transadaptacija“, dok Catford (1965: 41-43) upotrebljava termin „transkodiranje“ zbog karakteristične di- 
jamezijske transformacije teksta, odnosno promjene govornog koda u pisani. U kontekstu navedenih prijepora, Díaz Cintas (2004: 62) zaključuje da određeni tradicionalni termini i uvriježeni koncepti iz područja teorije prevođenja jednostavno nisu primjenjivi u okviru audiovizualnog prevođenja.

Određena je razina gubitka sadržaja u podslovima uvijek prisutna, a neminovan je i gubitak dramaturškog učinka kao posljedica dijamezijske transformacije teksta. U tom kontekstu Hervey i Higgins (1992: 159) upozoravaju da se obilježja govornog jezika pri dijamezijskoj transformaciji nipošto ne smiju u potpunosti zanemariti i izostaviti. Iako u podslovima nije moguće reproducirati sva obilježja nekog sociolekta ili idiolekta, ponekad je očuvanje takvih elemenata govornog jezika nužno za karakterizaciju pojedinih likova. U takvim se slučajevima prevoditelj može okrenuti kompromisnim rješenjima, primjerice, povremenoj uporabi kolokvijalnih ili žargonskih izraza (Georgakopoulou, 2003: 94).

Unatoč percepciji šire publike koja podslove smatra prijevodom filma, iz svega prethodno navedenog jasno je da je riječ o znatno složenijem procesu koji podrazumijeva tri simultane, komplementarne i jednako važne radnje; redukciju, dijamezijsku transformaciju i prijevod (Perego, 2005: 73). Iako Becquemont (1996: 153) opisuje podslov kao „suh i shematičan“ tekst koji ima prvenstveno referencijalnu funkciju, takav je oblik verbalne komponente $u$ potpunosti funkcionalan i prihvatljiv ciljnoj publici upravo zbog toga što su, kada je riječ o audiovizualnom prijevodu, verbalna, vizualna i slušna komponenta komplementarne u procesu stvaranja značenja.

\subsection{Uloga podslovljavanja u stjecanju prijevodne kompetencije}

Primjena tehnike podslovljavanja ima velik edukativni potencijal u okviru programa studija stranih jezika, ${ }^{2}$ a od osobitog je interesa uloga podslovljavanja u stjecanju prijevodne kompetencije na studijima prevoditeljskog usmjerenja. Zbog sve veće potrebe tržišta za audiovizualnim prevoditeljima, posebice u okviru podslovljavanja, nameće se i potreba njihova osposobljavanja za vrijeme studija.

Određenim je empirijskim istraživanjima utvrđeno da podslovljavanje predstavlja prije svega izuzetno motivirajuću aktivnost kojom se stječe vještina primjene specifičnih prijevodnih strategija (Beseghi, 2018; Incalcaterra McLoughin, 2009a; Incalcaterra McLaughin, 2009b; Williams i

\footnotetext{
${ }^{2}$ Vidi, primjerice, analitički pregled uporabe programa „Learning via Subtitling (LvS)“ ('Učenje putem podslovljavanja') u Sokoli (2007).
} 
Thorne, 2000). Navedenim je istraživanjima nepobitno utvrđena dobrobit integriranja tehnike podslovljavanja u prevoditeljske studijske programe što je potvrđeno i rezultatima dobivenim analizom upitnika namijenjenih studentima. Beseghi (2018: 188) navodi kako jako velik broj studenata, njih čak $93 \%$, smatra da su aktivnosti vezane za izradu podslova poboljšale razinu njihove prijevodne kompetencije.

Podslovljavanje nužno podrazumijeva sagledavanje polisemiotičkog teksta u njegovoj cjelovitosti čime pozornost studenta ne može biti usmjerena isključivo na verbalnu komponentu izvornika, nego na cjelovit komunikacijski čin. Također, spomenuta vremensko-prostorna ograničenja, koja uvjetuju djelomičnu ili potpunu redukciju izvornog teksta u podslovima, korisna su za razvijanje tekstualne kompetencije kroz praksu sažimanja izvornika. S druge strane, potreba za reduciranjem teksta u procesu prevođenja studentima onemogućuje oslanjanje na tehniku doslovnog prijevoda pa se njihova pozornost više usmjerava na postizanje idiomatičnosti ciljnog teksta. Nadalje, zbog učestale razlomljenosti dužih rečenica u dva ili više podslova, od izuzetne je važnosti ostvarenje sintaktičke kohezije u ciljnom tekstu. Uz sve navedeno treba također istaknuti i činjenicu da audiovizualni tekstovi redovito obiluju kulturološki obilježenim elementima, no, za razliku od prevođenja pisanih tekstova, u procesu podslovljavanja ne postoji mogućnost korištenja objasnidbenih bilješki (fusnota). Iz tog su razloga studenti primorani oslanjati se, primjerice, na kreativnu strategiju uporabe kulturoloških ili situacijskih ekvivalenata kako bi prijevod postao razumljiviji i prihvatljiviji ciljnoj publici.

Iako Di Toro (2013) tvrdi da se primjena različitih prijevodnih strategija događa spontano, na podsvjesnoj razini, neupitno je da dobro poznavanje postojećih prijevodnih strategija olakšava donošenje odluka koje su u slučaju podslovljavanja često vrlo zahtjevne. ${ }^{3}$ Poznavanje prijevodnih strategija umanjuje potrebu za improvizacijom, no istovremeno omogućava pronalaženje raznih kreativnih rješenja čime se razvija strateška kompetencija studenta (Chaume, 2004b: 13). Strukturiran pristup korištenju tehnike podslovljavanja, uz samu izradu podslova, podrazumijeva detaljnu analizu audiovizualnog teksta te prijevodnih strategija primijenjenih u službenim, a potom i u vlastitim podslovima. Navedenim se aktivnostima učinkovito razvija gramatička, sociolingvistička, tekstualna te strateška kompetencija budućeg prevoditelja (Incalcaterra McLaughin, 2009b: 183).

\footnotetext{
${ }^{3}$ Odluke o primjeni pojedinih strategija ponekad su orijentirane prema očuvanju koherentnosti i čitljivosti na uštrb sadržaja (Hatim i Mason 2000: 435). U tom smislu Nornes (1999: 18) podslovljavanje uspoređuje s prevođenjem poezije.
} 


\section{PRIJEVODNE STRATEGIJE U PODSLOVLJAVANJU}

U kontekstu klasifikacije ili taksonomije prijevodnih strategija koje se mogu primjenjivati u procesu podslovljavanja treba naglasiti da su razni autori predložili termine i definicije koje se podosta razilaze. Takva je heterogenost uvelike uvjetovana činjenicom da je zbog svoje polisemiotičnosti, odnosno zbog supostojanja slušne, vizualne i verbalne komponente, podslovljavanje uistinu vrlo kompleksan proces (Perego, 2005: 101).

\subsection{Gottliebov i Lomheimov model}

U nizu različitih pristupa prijevodnim strategijama u podslovljavanju, najcitiraniji su Gottliebov (1992) i Lomheimov (1999) model.

Gottlieb (1992: 166) u svojem modelu navodi sljedećih deset prijevodnih strategija: 1) ekspanzija, engl. expansion (dodavanje elemenata u prijevo$\mathrm{du}$, prvenstveno kod kulturološki uvjetovanih elemenata); 2) parafraza, engl. paraphrase (adaptacija teksta u skladu s ciljnim jezikom ili kulturom); 3) transfer, engl. transfer (doslovan prijevod); 4) imitacija, engl. imitation (preuzimanje riječi iz izvornika); 5) transkripcija, engl. transcription (pisana reprodukcija fonetičkih paronomazija); 6) dislokacija, engl. dislocation (izmjena ciljnog teksta uvjetovana specifičnim vizualnim ili akustičkim elementom); 7) kondenzacija, engl. condensation (sažimanje sadržaja brisanjem elemenata govornog jezika); 8) redukcija, engl. decimation (reduciranje sadržajno važnih elemenata); 9) brisanje, engl. deletion (potpuno izostavljanje sadržajno nevažnih elemenata) i 10) rezignacija, engl. resignation (izostavljanje neprevodivih izraza).

Gottliebov je model nastao na temelju studije slučaja danskih podslova filma Young Frankenstein, ali se zbog svoje kompleksnosti često pokazuje teško primjenjivim u praksi (Perego, 2005: 119; Lomheim, 1999: 202). Naime, razlike između pojedinih strategija izuzetno su suptilne pa je pri analizi korpusa često gotovo nemoguće sa sigurnošću provesti preciznu klasifikaciju. Posebice je to uočljivo kod strategija kojima se izvorni tekst pokraćuje (kondenzacija, redukcija i brisanje), a koje su istovremeno i najučestalije u podslovljavanju. Kao što se vidi iz prethodno navedenog, prema Gottliebovom modelu kondenzacija podrazumijeva sažimanje sadržaja putem izostavljanja elemenata karakterističnih za govorni jezik, dok redukcija također podrazumijeva izostavljanje elemenata koje, međutim, dovodi do određenih promjena na planu značenja izraza. Problem klasifikacije dodatno otežava činjenica da se na razini jednog podslova nerijetko uočava kombinacija više redukcijskih strategija. 
Zbog svega navedenog, Lomheim je imao za cilj razraditi nešto jednostavniju klasifikaciju koja bi bila lakše primjenjiva u praksi. Njegov prvotni model iz 1995. godine terminološki je modificiran 1999. godine i sastoji se od ukupno sedam strategija, a to su: 1) izostavljanje, engl. omission; 2) kompresija, engl. compression (sažimanje); 3) ekspanzija, engl. expansion (dodavanje elemenata); 4) generalizacija, engl. generalisation (uporaba općenitijeg izraza ili hiperonima), 5) specifikacija, engl. specification (uporaba hiponima); 6) neutralizacija, engl. neutralisation (zamjena izraza snažnog konotativnog značenja neutralnijim izrazom) i 7) prijevod, engl. translation. ${ }^{4}$

Lomheim (1999: 206) navedene strategije dodatno pojednostavljuje grupirajući ih u makrostrategije prijevoda, redukcije i ekspanzije. Makrostrategija redukcije uključuje izostavljanje i kompresiju, makrostrategiji prijevoda, uz ekvivalentan prijevod, pripadaju također i neutralizacija, generalizacija i specifikacija, dok strategija ekspanzije samostalno tvori istoimenu makrostrategiju. Navedeni je model, zbog svoje jasnoće i preglednosti, korišten u ovom istraživanju kao instrument pri analizi korpusa.

\subsection{Metode redukcije podslova}

O nužnosti primjene redukcijskih strategija u procesu podslovljavanja svjedoči i takozvani FAR model za objektivnu procjenu kakvoće podslova koji je razvio J. Pedersen (2017). Ime modela predstavlja akronim prema engleskim nazivima triju parametara koji se vrednuju pri procjeni kvalitete, a to su funkcionalna ekvivalencija (engl. functional equivalence), prihvatljivost (engl. acceptability) i čitljivost (engl. readability). Model se primjenjuje tako da se u okviru navedena tri parametra negativno vrednuju prijevodne pogreške, ovisno o njihovoj težini. Dok bi parametri funkcionalne ekvivalencije i prihvatljivosti mogli biti primjenjivi na sve vrste prijevoda jer se odnose na razinu značenja ciljnog teksta i njegovu gramatičku točnost, parametar čitljivosti primjenjiv je isključivo na podslovljavanje. Naime, pogreške u okviru navedenog parametra tiču se u prvom redu poštivanja maksimalnog broja znakova u podslovu koji je u izravnoj korelaciji s vremenskim okvirom njegova prikazivanja na ekranu, odnosno s brzinom kojom glumci izgovaraju izvorni tekst.

\footnotetext{
${ }^{4}$ Lomheim (1999: 200) termin 'prijevod' koristi sukladno definiciji ekvivalentnog prijevoda kao prirodnog ekvivalenta u ciljnom jeziku prvenstveno na značenjskoj, a onda i na stilskoj razini (Nida i Taber, 1974: 12).
} 
U kontekstu redukcije teksta, uz jasnu napomenu da nije uputno skraćivati izvorni tekst ako to nije nužno, Díaz Cintas i Remael (2007: 150-170) detaljno navode različite metode kompresije izvornog teksta kao i tipologiju elemenata koji mogu biti izostavljeni u ciljnom tekstu, a da se pri tom ne naruši njegova koherentnost. Kao što je već rečeno, kompresija teksta predstavlja postupak kojim izvorni tekst postaje koncizniji, a prema spomenutim autorima, moguće ga je komprimirati na sljedeće načine: uporabom jednostavnih umjesto složenih glagolskih vremena, pojednostavljenjem glagolskih perifraza, promjenom vrste riječi, uporabom jesnih umjesto niječnih rečenica, uporabom izravnog umjesto neizravnoga govora, uporabom izravnog umjesto neizravnog pitanja, inverzijom redoslijeda teme i reme, poopćavanjem nabrajanja, pretvorbom složene rečenice u jednostavnu, pretvorbom pasivne konstrukcije u aktivnu i obratno, uporabom zamjenica i drugih deiktičkih izraza te spajanjem više rečenica u jednu.

Elementi koji podliježu potpunoj redukciji ili izostavljanju su diskursne oznake, pridjevi, prilozi, uzvici, pozdravi, vokativni izrazi i ponavljanja. U prizorima u kojima, primjerice, postoji visoka razina buke pa se dijalog ne može jasno čuti ili ako istovremeno govori više ljudi, moguće je izostaviti čak i čitavu rečenicu. Georgakopoulou (2003: 220) u vrlo opsežnom istraživanju strategija podslovljavanja s engleskog na grčki jezik dolazi do zaključka da ekvivalentni prijevod i izostavljanje predstavljaju dvije najučestalije strategije.

\section{CILJ I METODOLOGIJA ISTRAŽIVANJA}

Ovo se istraživanje temelji na analizi hrvatskih podslova talijanskog filma Smetto quando voglio ('Mogu prestati kad god želim') koji predstavlja prvi dio vrlo uspješne trilogije talijanskog redatelja Sydneya Sibilie. ${ }^{5}$ Glavni protagonist filma, tridesetogodišnjak Pietro Zinni, iako vrlo uspješan znanstvenik neurobiolog, proglašen je tehnološkim viškom na svom fakultetu te, kako bi zaradio za život, okuplja oko sebe „bandu intelektualaca“. Riječ je o njegovim bivšim kolegama koji, baš poput njega, jedva preživljavaju jer ne uspijevaju pronaći posao u struci. Zajedničkim snagama uspijevaju ostvariti veliku zaradu proizvodnjom i prodajom "pametne droge“ koja se ne nalazi na službenom popisu ilegalnih supstanci u Italiji.

\footnotetext{
${ }^{5}$ Drugi i treći nastavak trilogije pod naslovom Smetto quando voglio: Masterclass i Smetto quando voglio: Ad honorem snimljeni su 2017. godine.
} 
Odabir navedene kriminalističke komedije kao predmeta analize u ovom radu uvjetovan je činjenicom da je, s aspekta tehnike podslovljavanja, riječ o vrlo kompleksnom filmu. Prije svega, učestali brzi ritam govora te zgusnuti dijalozi upućuju na nužnost primjene redukcijskih strategija. Istovremeno, obilje leksičkih elemenata karakterističnih za razgovorni stil, poput žargonizama, vulgarizma i dijalektizama, uz specifičnu upotrebu brojnih neprilagođenih riječi iz engleskog jezika, očekivano su u izravnoj vezi sa strategijom izostavljanja ili pak neutralizacije elemenata u ciljnom tekstu. ${ }^{6}$ Drugim riječima, takav izvorni tekst predstavlja zahtjevan zadatak za prevoditelja koji je, vodeći računa o svim tehničkim uvjetima koje kvalitetan podslov treba zadovoljiti, primoran pribjeći značajnim prilagodbama teksta kako bi ostvario optimalno prijevodno rješenje.

Nakon što je film odgledan u cijelosti, pristupilo se prikupljanju korpusa transkripcijom izvornog audiozapisa filma, a potom i hrvatskih podslova. Usporedbom transkribiranog izvornika i podslova identificirane su primijenjene prijevodne strategije sukladno Lomheimovoj taksonomiji iz 1999. godine. U konačnici je provedena kvantitativna analiza svih prijevodnih strategija odnosno kvalitativna analiza odabranih primjera strategija koje su se pokazale najzastupljenijima.

S obzirom na činjenicu da su strategije izostavljanja i kompresije očekivano najčešća sredstva prilagodbe ciljnog teksta u podslovljavanju, posebna je pozornost posvećena detaljnoj analizi različitih metoda redukcije teksta prema klasifikaciji koju navode Díaz Cintas i Remael (2007). Kvalitativnom se analizom pokušava odgovoriti na pitanje narušava li primjena redukcijskih strategija koherentnost ciljnog teksta. Istovremeno se pokušava utvrditi na koji su način obilježja govornog jezika prilagođena u ciljnom tekstu te u kojoj je mjeri primjena neutralizacije takvih obilježja utjecala na jezičnu karakterizaciju filmskih protagonista.

\section{REZULTATI ANALIZE I RASPRAVA}

Prikaz rezultata kvantitativne analize prijevodnih strategija identificiranih u prikupljenom korpusu donosi se u Tablici 1 .

\footnotetext{
${ }^{6}$ U karakteristike razgovornog stila na leksičkoj razini, Silić (2006: 110) svrstava vulgarizme, dijalektizme, regionalizme i barbarizme. Frančić, Hudeček i Mihaljević (2005: 243) smatraju da i žargonizmi pripadaju razgovornom funkcionalnom stilu, ali ne i razgovornom funkcionalnom stilu hrvatskoga standardnog jezika.
} 
Tablica 1. Zastupljenost prijevodnih strategija u hrvatskim podslovima

\begin{tabular}{l|c|c}
\hline Strategija & Broj primjera & Udio u korpusu \\
\hline ekvivalentan prijevod & 817 & $70,7 \%$ \\
\hline izostavljanje & 226 & $19,5 \%$ \\
\hline kompresija & 59 & $5,1 \%$ \\
\hline neutralizacija & 47 & $4,1 \%$ \\
\hline generalizacija & 5 & $0,4 \%$ \\
\hline specifikacija & 0 & $0 \%$ \\
\hline ekspanzija & 0 & $0 \%$ \\
\hline
\end{tabular}

Iz Tablice 1. jasno proizlazi da je ekvivalentan prijevod najzastupljenija prijevodna strategija s udjelom od 70,7\%. Na drugom, odnosno trećem mjestu su redukcijske strategije izostavljanja i kompresije s ukupnim udjelom od 24,6\%. Navedeni udio dviju redukcijskih strategija u podslovima potvrđuje već spomenute rezultate istraživanja koje je proveo Lomheim (1995). Valja ipak istaknuti da je Georgakopoulou (2003) u svojem istraživanju utvrdila da je udio redukcijskih strategija izuzetno podložan varijaciji ovisno o filmskom žanru. Spomenuta autorica na temelju kvantitativnih podataka svojeg empirijskog istraživanja također zaključuje da usporedba broja riječi u izvorniku i ciljnom tekstu može predstavljati objektivnu metodu izračuna udjela redukcijskih strategija. Ovakav je zaključak u opoziciji sa stavom koji na temelju vlastitog empirijskog istraživanja iznosi Lomheim (1999: 191) zaključujući da smanjenje broja riječi u prijevodu često nije uvjetovano primjenom redukcijskih strategija, nego razlikama u leksičkoj strukturi jezika.

U kontekstu karakteristične tendencije ka skraćivanju izvornog teksta, ne iznenađuje što strategija ekspanzije kao ni strategija specifikacije nisu predstavljale metode izbora u izradi podslova. Strategija neutralizacije, kao četvrta po učestalosti među sedam strategija, jasan je odraz obilježja razgovornog stila analiziranog filma u kojem, kako je već prethodno rečeno, uz žargonizame i dijalektizme, dominiraju vulgarizmi. Generalizacija ili uporaba općenitijeg izraza korištena je pak kao prijevodna strategija kulturoloških elemenata. Riječ je o svega nekoliko primjera koji sadrže imena različitih objekata ili institucija pa su tako, primjerice, umjesto imena poznatog rimskog sveučilišta La Sapienza ili imena palače Montecitorio, sjedišta dijela talijanskog parlamenta, u podslovima upotrijebljeni općeniti pojmovi „fakultet" odnosno „parlament". 


\subsection{Podslov kao ekvivalentan prijevod}

Premda audiovizualno prevođenje umnogome odstupa od tradicionalne definicije tog pojma, rezultati analize ipak pokazuju da je upravo ekvivalentan prijevod dominantan u odnosu na sve ostale strategije. Takav je prijevod moguć isključivo u onim dijelovima teksta u kojima su dijalozi kratki ili je ritam govora sporiji. Drugim riječima, izuzetno je važno da ekvivalentan prijevod ne naruši parametar čitljivosti koji ne dozvoljava uporabu više od 74 znakova u jednom podslovu te da njegovo trajanje na ekranu bude u skladu s njegovom duljinom. Analizom primjera iz korpusa utvrđeno je da je ekvivalentan prijevod korišten u brojnim dijalozima koji se sastoje od kraćih rečenica i u kojima nije bilo potrebe za pokraćivanjem teksta odnosno eliminiranjem ili neutraliziranjem vulgarizama, kao u primjerima $(1 \mathrm{a}-\mathrm{c})$ :

(1a) Pietro, sei in bagno?

Pietro, u kupaonici si?

(1b) No, ho fatto. Eccomi.

Ne, gotov sam. Evo me.

(1c) Ma che c'è? Hai una voce strana.

Što je bilo? Glas ti je čudan.

Za razliku od sinkronizacije koja iz različitih razloga često primjetno odstupa od izvornika, manevarski je prostor u procesu podslovljavanja znatno manji. Naime, čitajući podslove, ciljna publika istovremeno sluša i zvučni zapis te, ako donekle poznaje izvorni jezik, može uočiti određene izmjene u ciljnom tekstu. Takve izmjene, ako su učestale, mogu se doživjeti kao prijevodne pogreške što $u$ konačnici može dovesti u pitanje i pouzdanost samog prevoditelja (Díaz Cintas, 2014: 303). Slično tome, vrlo kratak podslov uz poduži dijalog može također imati negativan učinak na ciljnu publiku koja će u takvim slučajevima zasigurno uočiti nesklad između zvučnog zapisa i podslova (Díaz Cintas i Remael, 2007: 150).

Nadalje, kao što je već rečeno, uporabom žargonizama u podslovima nastoji se sačuvati jezičnu i socijalnu karakterizaciju likova s obzirom na činjenicu da se većina obilježja govornog jezika neizbježno gubi uslijed dijamezijske transformacije teksta. Tendencija uporabe žargonskih izraza u podslovima uočena je prilikom kvalitativne analize kategorije ekvivalentnog prijevoda što se ogleda u primjerima $(2 \mathrm{a}-\mathrm{b})$ :

(2a) Però che casino per gli spiccioli! Ali kakva strka zbog sitne love! 
(2b) Sono stato dentro due anni per non fare l'infame con un amico. Odgulio sam dvije godine zatvora da ne bih cinkao prijatelja.

U primjeru (2a) izraz spiccioli (tal. 'sitan novac') preveden je žargonskim izrazom „sitna lova“, a ekvivalentnim žargonizmima "odguliti“ i „cinkati“ prevedeni su također i talijanski kolokvijalni frazemi stare dentro ('biti u zatvoru') i fare l'infame ('biti izdajnik') u primjeru (2b).

\subsection{Neutralizacija izvornog teksta}

Dijamezijska transformacija govornog u pisani jezik utječe na prijevodne odabire posebice kada je riječ o vulgarizmima ili općenito različitim tabuizrazima. Iako se takve riječi obično izostavljaju u ciljnom tekstu i to često zbog vremensko-prostornih ograničenja kojima podslovi podliježu, njihovo neselektivno izostavljanje katkad ne predstavlja najbolje rješenje. Prije svega, nužno je utvrditi i procijeniti funkciju odnosno učinak određene riječi u izvornoj i u ciljnoj kulturi jer različite kulture imaju i različite stavove o tome što predstavlja tabu, odnosno što je u tom kontekstu prihvatljivo, a što nije.

Uporaba tabu-izraza u govoru nikad nije kaotična, beznačajna ili slučajna (Jay, 2000: 22). Jezični tabui u filmu imaju svoju funkciju i važan su element u karakterizaciji likova pa je poželjno pronaći način da ih se zadrži u ciljnom tekstu. Iako je potpuna neutralizacija takvih izraza u podslovima vrlo česta, na taj se način potencijalno može promijeniti gledateljevo poimanje filmskih likova, a u konačnici i poimanje samog sadržaja filma (Díaz Cintas i Remael, 2007: 196-198). Riječ je, dakle, o složenoj pojavi koja čini sastavni dio nečijeg identiteta i društvene pripadnosti, no, unatoč tome, izostavljanje tabu-izraza najčešće nije uvjetovano vremensko-prostornim ograničenjima, nego subjektivnim odabirom prevoditelja te eventualnim uputama klijenata (Ávila Cabrera, 2015).

U filmu Smetto quando voglio mladi perspektivni znanstvenici silom prilika ulaze u mračni svijet kriminalaca i dilera i ta se činjenica ogleda i na jezičnom planu. Naime, u određenim se dijelovima teksta uočavaju brojni kompleksni termini iz područja kemije koji su vezani za proces stvaranja pametne droge te su prevedeni formalnim ekvivalentima. S druge je strane istovremeno prisutan i cijeli niz vulgarnih izraza koji su ili neutralizirani ili izostavljeni u ciljnom tekstu. Među njima dominira vulgarizam cazzo (tal. vulg. 'muški spolni organ') odnosno njegove različite izvedenice poput incazzarsi, scazzo, rompicazzo ili cazzata za koje je u hrvatskim podslovima redovito upotrijebljen neki oblik eufemizma, kao u primjerima (3a-e): 
(3a) Ma che cazzo stai a di??

Dovraga, o čemu pričaš?

(3b) Adesso vai via che questo si incazza e c'ha pure ragione.

Sad idi jer će on poludjeti $i$ ima pravo.

(3c) Abbiamo avuto uno scazzo un po' pesante.

Žestoko smo se posvadali.

(3d) Che rompicazzo!

Kakav gnjavator!

(3e) Basta con 'ste cazzate!

Dosta s tim glupostima!

U iznimno su rijetkim slučajevima takvi izrazi izostavljeni u podslovima (v. odjeljak 5.3.1.), a njihovo je izostavljanje, kao i ublažavanje, uvjetovano činjenicom da pisana riječ u podslovima ima znatno snažniji učinak na primatelja poruke negoli riječ koja je izgovorena (Díaz Cintas, 2001: 51; Petillo, 2012: 142). ${ }^{7}$ Drugim riječima, vrlo je vjerojatno da bi doslovni prijevodi niza vulgarnih izraza kod mnogih pripadnika publike izazvali osjećaj nelagode.

Analizom prikupljenog korpusa podslova utvrđeno je da vulgarizmi i psovke ni u jednom slučaju nisu doslovno prevedeni pa se može reći da je redovita primjena neutralnih izraza neminovno utjecala na jezičnu karakterizaciju protagonista navedenog filma, a posljedično i na percepciju istih od strane ciljne publike. Činjenica je da se ponekad, uslijed uporabe neutralnih izraza, dijalozi mogu doimati neprirodnima, kao, primjerice, $u$ prizorima izrazito agresivnog naboja. U takvim je slučajevima tekst podslova u neskladu $\mathrm{s}$ informacijama koje ciljna publika prima putem vizualne i zvučne komponente. Dok izostavljanje vulgarnog izraza može biti posljedica vremensko-prostornih ograničenja, to očigledno nije slučaj kod upotrebe eufemizama.

Vulgarizmi u izvornom tekstu u primjerima (3c) i (3e) također su i dijatopijski obilježeni pa u tom kontekstu valja spomenuti da je strategija neutralizacije primijenjena i na rijetke dijalektalne izraze koji se pojavljuju u izvornom tekstu. ${ }^{8}$ Radnja filma odvija se u Rimu i svi protagonisti govore

\footnotetext{
${ }^{7}$ Unatoč tome, primjena neutralizacije vulgarizama karakteristična je također i za sinkronizaciju. Naime, s obzirom na to da vulgarizmi sami po sebi nisu važni za radnju filma, odnosno da predstavljaju tek izraz određenih emocija ili stavova, uvriježeno je mišljenje da ih nije nužno (doslovno) prevesti (Pavesi, 2005: 48).

${ }^{8}$ Strategija neutralizacije dijatopijskih varijacija redovita je pojava u podslovljavanju. Pronalaženje ekvivalentnog dijalekta u ciljnom jeziku najčešće nije moguće jer konotacije određenog dijalekta ciljnog
} 
rimskim dijalektom pa se može zaključiti da je neutralizacija dijalekta u ciljnom tekstu sasvim opravdana jer dijatopijska varijacija u izvorniku nema razlikovnu ulogu u karakterizaciji likova.

Osim u slučaju vulgarizama i elemenata rimskog dijalekta, prijevodna strategija neutralizacije uočena je i kod uporabe riječi iz engleskog jezika koje predstavljaju vrlo karakteristično obilježje sociolekta filmskih protagonista. Prema podjeli posuđenica sukladno stupnju njihove prilagođenosti, koju navode Frančić, Hudeček i Mihaljević (2005: 209), u ovom se slučaju radi isključivo o stranim riječima, odnosno o riječima potpuno neprilagođenima jeziku u kojem se koriste. Takve posuđenice iz luksuza koje u jezik ne uvode ni novo značenje ni novi pojam, opisuju se kao manifestacije kozmopolitizma, superiornosti i prestiža, pri čemu je forma važnija od sadržaja (Italiano, 1999: 4). Navedene implikacije koje proizlaze iz uporabe neprilagođenih engleskih riječi u dijalozima analiziranog filma, $u$ hrvatskim su podslovima u potpunosti izgubljene uporabom riječi ili izraza iz hrvatskoga standardnog jezika, kao što je razvidno iz primjera (4a-c):

(4a) Questo calo di adrenalina mi ha causato un down di potassio. Ovaj pad adrenalina mi je uzrokovao smanjenje kalija.

(4b) Cominceremo facendo un po' di self marketing per farci conoscere. Počet ćemo sa samopromocijom kako bi nas upoznali.

(4c) Noi veniamo da una situazione di open space post industriale. Mi dolazimo iz postindustrijskog okruženja otvorenog prostora.

U procesu je podslovljavanja komunikacijska funkcija od primarne važnosti (Díaz Cintas, 2014: 307). Stoga je ovakav prijevodni odabir, za koji se može reći da je suprotan tendenciji očuvanja obilježja sociolekata, vjerojatno uvjetovan potrebom da podslov bude lako razumljiv široj publici koja ne mora nužno dobro poznavati engleski jezik

\subsection{Redukcija izvornog teksta}

S obzirom na činjenicu da se strategije izostavljanja i kompresije najčešće preklapaju, Lomheim (1999: 206) u shematskom prikazu svog modela navodi makrostrategiju redukcije koja uključuje obje navedene strategije. Makrostrategija redukcije temeljna je specifičnost tehnike profesionalnog podslovljavanja na tragu nepisanog pravila struke da se filmovi trebaju gle- 
dati, a ne čitati (Díaz Cintas, 2014: 302). U nastavku se donose primjeri različitih metoda kojima je u procesu podslovljavanja provedena redukcija izvornog teksta.

\subsubsection{Izostavljanje}

Kvantitativnom je analizom utvrđeno da je izostavljanje druga najčešće primjenjivana strategija u podslovljavanju analiziranog filma. Klasifikacijom elemenata izostavljenih u podslovima zaključuje se da je riječ o sljedećih sedam kategorija: diskursne oznake (63,7 \%); vokativni izrazi (21,2 \%); prilozi/priložne oznake (5,3\%); vulgarizmi (3,5 \%); pridjevi (3,1 \%); ponavljanja $(1,7 \%)$ i pleonazmi (1,3 \%). Navedeni elementi najčešće nemaju osobitog utjecaja na značenje rečenice $u$ audiovizualnom tekstu te se njihovim izostavljanjem smanjuje broj znakova u podslovu, a pozornost publike postaje više usmjerena na radnju filma, odnosno na sadržaj vizualnog kanala. ${ }^{9}$

Diskursne oznake pripadaju različitim morfološkim i sintaktičkim kategorijama i funkcionalno su raznorodne, a zbog dijamezijske transformacije teksta u podslovljavanju predstavljaju element koji je najpodložniji izostavljanju. Riječ je o izrazima kao što su, primjerice, oserei dire 'usudio bih se reći'; ho capito 'shvatio sam'; sentimi ‘slušaj me'; vero 'zar ne' koji su istaknuti u primjerima $(5 \mathrm{a}-\mathrm{d})$ :

(5a) Oserei dire, quasi da paradosso helleriano.

Ø Skoro kao Hellerov paradoks.

(5b) Ho capito, ma almeno 1500?

$\varnothing$ Barem 1500 eura?

(5c) Sentimi, mettiamo su una banda.

Ø Osnovat ćemo bandu.

(5d) Era una fattura importante, vero?

To je bio neki važan račun Ø?

Izostavljanjem diskursnih oznaka u navedenim se primjerima ne mijenja propozicijski sadržaj iskaza. Drugim riječima, komunikacijski ciljevi ili namjera govornika nisu ugroženi ukoliko su diskursne oznake izostavljene što ukazuje da spadaju u opcionalne elemente. (Badurina, 2018: 65).

Nadalje, s obzirom na činjenicu da su u audiovizualnom tekstu vizualna, slušna i verbalna komponenta komplementarne, odnosno da publika na

\footnotetext{
${ }^{9}$ Više o teoriji koja opovrgava tezu o minornosti diskursnih oznaka u audiovizualnom prijevodu vidi u Mattsson (2009).
} 
ekranu može vidjeti tko koga oslovljava u određenom trenutku, vokativni izrazi također predstavljaju element koji je u velikom broju slučajeva redundantan: ${ }^{10}$

(6a) Professore, è finita l'ora.

$\emptyset$ Sat je završio.

(6b) Maurizio, adesso tu accosti e mi dai i soldi che mi devi!

Ø Zaustavi se i vrati mi lovu koju si mi dužan!

U ovom je kontekstu važno naglasiti da oslovljavanje, osim što može podrazumijevati provjeru kvalitete komunikacijskog kanala, odnosno namjeru uspostavljanja komunikacije s osobom kao u primjerima (6a-b), može također podrazumijevati i govornikovo karakteriziranje sugovornika (Karlić i Cvitković, 2016: 229). Analizom korpusa utvrđeno je da u potonjem slučaju vokativni izrazi, bilo da je riječ o izrazima od milja ili uvredljivim izrazima, u pravilu ne podliježu izostavljanju u podslovima, a što je razvidno iz primjera ( $7 \mathrm{a}-\mathrm{b})$ u nastavku:

(7a) Amore, che hai combinato stavolta?

Ljubavi, što si ovaj put učinio?

(7b) Coglione, io mò che dico al lavoro?

Budalo, što ću reći na poslu?

Vodeći se spomenutim načelom relevantnosti i ekonomičnosti u podslovima, prevoditelj je očekivano uklonio pleonazme, odnosno gomilanja riječi ili izraza istog značenja (Silić, 2006: 37) kao u primjeru (8) u kojem je iz tog razloga u podslovu izostavljen izraz ognuno di voi 'svakog od vas':

(8) Vi ho delusi tutti, ognuno di voi. Svih sam vas razočarao Ø.

$\mathrm{Na}$ isti su način uklonjena i različita ponavljanja, kao u primjeru (9) u kojem je izostavljen ponavljajući imperativni izraz Vieni giù! ('Spusti se!'):

(9) Vieni immediatamente giù, dobbiamo parlare! Vieni giù! Spusti se, moramo razgovarati! Ø

\footnotetext{
${ }^{10}$ Detaljnije o obrascima prevođenja i izostavljanja vokativa u podslovima u različitim filmskim žanrovima vidi u Bruti i Perego (2008).
} 
U navedenom je primjeru također izostavljen i prilog immediatamente ('odmah') koji u tom kontekstu ne utječe značajno na sadržaj iskaza. Međutim, prilozi/priložne oznake i pridjevi, za razliku od, primjerice, diskursnih oznaka, katkad mogu predstavljati element koji je sadržajno važan. $\mathrm{Ne}$ iznenađuje, stoga, što su primjeri njihove eliminacije rjeđi te se čini kako su prvenstveno uvjetovani formalnim ograničenjima odnosno parametrom čitljivosti. U primjeru (10) ciljni bi tekst morao biti segmentiran u dva podslova ako priložna oznaka vremena negli ultimi mesi ('prije nekoliko mjeseci') ne bi bila izostavljena: ${ }^{11}$

(10) Negli ultimi mesi ho messo su una banda che gestisce un giro d'affare di centinaia di migliaia di euro.

Ø Osnovao sam bandu koja upravlja poslom vrijednim 100 tisuća eura.

Naposljetku, kao što je već prethodno rečeno, vulgarizmi su u ciljnom tekstu najčešće neutralizirani uporabom eufemizama. Međutim, u manjem su broju slučajeva, kao u primjerima (11a-b), navedeni elementi izostavljeni u prijevodu:

\section{(11a) Che cazzo ci fai qua? \\ Što $\varnothing$ ti tu radiš? \\ (11b) Questo è un cazzo di fenomeno di marketing! Ovo je Ø marketinški fenomen!}

Na temelju tipologije elemenata koji su izostavljeni u podslovima može se zaključiti da takav način skraćivanja ciljnoga teksta ne utječe na smisao iskaza u cjelini te ne narušava njegovu koherentnost. Jasno je, dakle, da očuvanje svih elemenata izvornog teksta u podslovima nije moguće, ali nije ni potrebno jer podslovi ciljnoj publici služe kao „vodič“ ili pomoćno sredstvo u praćenju i razumijevanju audiovizualnog teksta koji je po svojoj prirodi polisemiotičan (Pavlović, 2002: 396).

\subsubsection{Kompresija}

Strategija kompresije u načelu je zahtjevnija od strategije izostavljanja elemenata, no predstavlja vrlo učinkovito sredstvo skraćivanja izvornog teksta.

\footnotetext{
${ }^{11}$ Ipak, unatoč nastojanju da svaki podslov bude cjelovita rečenica, u praksi se često nalaze primjeri segmentiranja dužih rečenica u dva ili više podslova (Díaz Cintas i Remael, 2007: 174).
} 
Vrlo je česta istovremena primjena strategije kompresije i izostavljanja zbog čega se, kako je već rečeno, ove strategije svrstavaju u makrostrategiju naziva „redukcijske strategije“. Analizom korpusa uočeno je sljedećih sedam metoda kompresije izvornika: pretvorba složene rečenice u jednostavnu (45,7 \%); pretvorba upravnog govora u neupravni $(15,2 \%)$; spajanje više rečenica u jednu (15,2\%); uporaba jednostavnog umjesto složenog glagolskog vremena $(8,4 \%)$; uporaba deiktičkih izraza (6,7 \%); pretvorba pasivnih konstrukcija u aktivne (5\%) i pretvorba niječnih rečenica u jesne (3,3\%).

Iz navedenih metoda kompresije jasno proizlazi da u okviru ove redukcijske strategije dominiraju različite sintaktičke transformacije kojima se izraz pojednostavljuje pri čemu ne dolazi do izmjena na planu značenja izvornog iskaza ili su one minimalne. Pretvorba upravnog u neupravni govor, kao u primjeru (12), jedna je od najčešćih metoda kompresije teksta: ${ }^{12}$

(12) Ho detto: "Guarda che noi abbiamo dei valori cattolici in comune." ('Rekao sam: "Vidite da mi imamo zajedničke katoličke vrijednosti")) Rekao sam mu da su nam katoličke vrijednosti zajedničke.

Strategija kompresije nerijetko podrazumijeva istovremenu primjenu više različitih metoda te se u primjeru (13) uočava i kombinacija metoda pretvorbe upravnog u neupravni govor i spajanja dviju rečenica u jednu. Isti primjer također ilustrira i činjenicu kako je metodom spajanja više rečenica iz izvornog teksta $u$ jednu rečenicu u ciljnom tekstu moguće eliminirati određena ponavljanja informacija:

(13) Questa cosa li aiuta. Infatti, mi hanno detto:,Non sai quanto ci aiuta".

('Ova nam stvar pomaže. Naime, rekli su mi: „Ne znaš koliko nam pomaže.')

Pomaže im to, tako su mi rekli.

$\mathrm{Na}$ sličan je način metodom pretvorbe složene rečenice u jednostavnu eliminirana tautologija u primjeru (14):

(14) Ma se dico che il tris è sospetto, è perché è sospetto.

('Ali ako kažem da je triplet sumnjiv, to je zato što je sumnjiv.'). Ali triplet je sumnjiv.

${ }^{12}$ Kod navođenja primjera kompresije teksta, u zagradama se donosi doslovan prijevod izvornika. 
Zbog postojanja vizualne komponente kod audiovizualnih tekstova, uporaba deiktičkih izraza predstavlja vrlo učinkovitu metodu kompresije izvornog iskaza kojom se podslov značajno skraćuje, a da se pri tome ne narušava koherentnost ciljnog teksta. U primjeru (15) ciljni je tekst znatno pokraćen upotrebom deiktičkog mjesnog priloga "tu“ koji upućuje na objekt koji se u tom trenutku nalazi u blizini sugovornika:

(15) Lo spazio della toilette discrimina in base al genere. ('Prostor toaleta diskriminira na temelju spola.') Tu vlada spolna diskriminacija.

Uporaba jednostavnog umjesto složenog glagolskog vremena također je jedan od načina reduciranja broja znakova u podslovu. U primjeru (16) umjesto kondicionala upotrijebljen je prezent glagola „željeti“:

(16) Tu vorresti mettere su una banda di spacciatori? ('Bi li želio osnovati bandu dilera?')

Želiš li osnovati bandu dilera?

Primjer (17) ilustrira smanjenje broja znakova u ciljnome tekstu zamjenom pasivne konstrukcije può essere letta ('može biti sagledana') aktivnim oblikom „možemo sagledati“, uz izostavljanje priloga totalmente 'potpuno' :

(17) La situazione può essere letta da un punto di vista totalmente positivo.

('Situacija može biti sagledana s potpuno pozitivne strane.')

Ovu situaciju možemo sagledati s pozitivne strane.

Naposljetku, u iznimno rijetkim slučajevima, prevoditelj je postigao određenu razinu kompresije teksta jednostavnom preformulacijom niječnih rečenica u jesne, kao u primjeru (18):

(18) Non può non sapere rispondere alle domande.

('Ne možete ne znati odgovoriti na pitanja.')

Morate znati odgovoriti na pitanja.

\section{ZAKLJUČAK}

Ovaj je rad imao za cilj kvantificirati i opisati prijevodne strategije primijenjene u procesu podslovljavanja talijanskog filma Smetto quando voglio 
na hrvatski jezik. Iako je u uvodnom dijelu istaknuto da se podslovljavanje ne smatra prevođenjem, nego prilagodbom ciljnog teksta, kvantitativna je analiza pokazala da je ekvivalentan prijevod najčešće primjenjivana strategija u podslovljavanju analiziranog filma. Riječ je, naime, o brojnim kratkim dijalozima koji su se u izvornom obliku mogli u potpunosti uklopiti u vremensko-prostorna ograničenja kojima podslovi podliježu.

Međutim, kvantitativna analiza također potvrđuje da su redukcijske strategije kompresije i izostavljanja najčešća sredstva prilagodbe izvornog teksta kao izravna i neminovna posljedica navedenih tehničkih ograničenja u podslovljavanju. Detaljnom analizom izostavljenih elemenata i različitih metoda kompresije izvornog teksta utvrđeno je da njihovom primjenom nije narušena koherentnost ciljnog teksta s obzirom na to da elementi koji su najčešće izostavljani, poput diskursnih oznaka ili vokativnih izraza, ne utječu na propoziciju iskaza. Uslijed kraćenja ili sažimanja ciljnog teksta pozornost je publike više usmjerena na radnju filma, to jest na vizualnu komponentu audiovizualnog teksta.

S druge strane, primjena strategije neutralizacije neizbježna je posljedica dijamezijske transformacije teksta jer ono što je prihvatljivo u govoru, nije uvijek prihvatljivo i u pisanom jeziku. S obzirom na činjenicu da izvorni dijalozi obiluju vulgarizmima, ova se strategija po svojoj učestalosti u kvantitativnoj analizi nalazi odmah iza redukcijskih strategija. Iako su vulgarizmi u određenoj mjeri izostavljani u ciljnom tekstu, u najvećem su broju slučajeva ublaženi uporabom eufemizama. Može se reći da je neutralizacijom vulgarizama, kao i prevođenjem neprilagođenih engleskih riječi na hrvatski jezik, uvelike oslabljena jezična karakterizacija filmskih protagonista. Povremenom je uporabom žargonskih izraza ipak izbjegnuta potpuna neutralizacija stila na makrorazini teksta.

Daljnjim istraživanjima na opsežnijem korpusu talijanskih filmova trebalo bi dodatno potvrditi ili pak opovrgnuti rezultate koji su proizašli iz ove studije slučaja. Nadalje, na temelju reprezentativnog korpusa filmova bilo bi moguće istražiti i korelaciju između strategija prilagodbe podslova i filmskog žanra. Drugačije rečeno, primjenom kvantitativne i kvalitativne analize na heterogenom korpusu talijanskih filmova moglo bi se utvrditi $u$ kojoj su mjeri primjene strategija prilagodbe ciljnog teksta poput redukcije i neutralizacije uvjetovane karakterističnim obilježjima različitih filmskih žanrova. 


\section{LITERATURA}

Ávila-Cabrera, J. J. (2015) Subtitling Tarantino's offensive and taboo dialogue exchanges into European Spanish: the case of Pulp Fiction. Revista de Linguística y Lenguas Aplicadas, 10(1), 1-11.

Badurina, L. (2018) O semantici i pragmatici diskursnih oznaka. U Badurina, L. i Palašić, N. (ur.) Riječki filološki dani 11. Rijeka: Filozofski fakultet, 63-74.

Becquemont, D. (1996) Les Sous-titrages cinématographiques : contraintes, sens, servitudes. U Gambier, Y. (ur.) Les transferts linguistiques dans les médias audiovisuels. Pariz: Presses universitaires du Septentrion, 145-155.

Beseghi, M. (2018) Developing students' translation competence and intercultural awareness through subtitling. A didactic proposal. Iperstoria, 12, 178-191.

Bruti, S., i Perego, E. (2008) Vocatives in subtitles: A survey across genre. U Cristopher, T. (ur.) Ecolingua. The role of e-corpora in translation, language learning and testing. Trst: EUT, 11-51.

Catford, J. C. (1965) A linguistic theory of translation. Oxford: OUP.

Chaume, F. (2004a) Cine y traducción. Madrid: Cátedra.

Chaume, F. (2004b) Film Studies and Translation Studies: Two Disciplines at Stake in Audiovisual Translation. META, 49 (1), 12-24.

Di Toro, F. (2013) Strategie di sottotitolazione nella classe di italiano come lingua straniera (Neobjavljeni doktorski rad). Italija: Sveučilište u Bolonji.

Díaz Cintas, J. (2001) Sex, (sub)titles and videotapes. U García, L. L. i Pereira Rodríguez, A. M. (ur.) Traducción subordinada II: el subtitulado (inglés - español/galego). Valencia: Universidad de Valencia, 85-99.

Díaz Cintas, J. (2004) Subtitling: The Long Journey to Academic Acknowledgement. The Journal of Specialized Translation, 1, 50-70.

Díaz Cintas, J. i Remael, A. (2007) Audiovisual translation: subtitling. London: Routledge.

Díaz Cintas, J. (2014) La questione della qualita' nel sottititolaggio. U Garzelli, B. i Baldo, M. (ur.) Subtitling and Intercultural Communication: European Languages and Beyond. Pisa: Edizioni ETS, 290-312.

d'Ydewalle, G., Van Rensbergen, J. i Pollet, J. (1987) Reading a message when the same message is available auditorily in another language: The case of subtitling. U O’Regan, J. K. i LévySchoen, A. (ur.) Eye movements: From physiology to cognition. Amsterdam: North-Holland, 313-321.

Frančić, A., Hudeček, L. i Mihaljević, M. (2005) Normativnost $i$ višefunkcionalnost u hrvatskome standardnom jeziku. Zagreb: Hrvatska sveučilišna naklada.

Gambier, Y. (2003) Introduction: Screen transadaptation: Perception and reception. Translator, 9 (2), 171-189.

Georgakopoulou, P. (2003) Reduction levels in Subtitling. DVD Subtitling: A Compromise of Trends. (Neobjavljeni doktorski rad). Guildford: University of Surrey

Gottlieb, H. (1992) Subtitling - A New University Discipline. U Dollerup, C. i Loddegaard, A. (ur.) Teaching Translation and Interpreting: Training, Talent, and Experience. Amsterdam: John Benjamins, 161-170.

Gottlieb, H. (2004) Subtitles and International Anglification. Nordic Journal of English Studies, 3 (1), 219-230. 
Hatim, B. i Mason, I. (2000) Politeness in Screen Translating. U Venuti, L. (ur.) The Translation Studies Reader. London and New York: Routledge, 430-45

Hervey, S. i Higgins, I. (1992) Thinking Translation: A Course in Translation Method: French to English. London: Routledge.

Incalcaterra McLoughlin, L. (2009a) Inter-semiotic Translation in Foreign Language Acquisition: The Case of Subtitles. U Witte, A., Harden, T. i Ramos de Oliveira Harden, A. (ur.) Translation in Second Language Learning and Teaching. Bern: Peter Lang, 227-244.

Incalcaterra McLoughlin, L. (2009b) Subtitles in Translators' Training: A Model of Analysis. Romance Studies, 27(3), 174-185.

Italiano, G. (1999) Parole a buon rendere: ovvero l'invasione dei termini anglo-americani. Cadmo: Fiesole.

Jay, T. (2000) Why we curse: A neuro-psycho-social theory of speech. Philadelphia: John Benjamins.

Karlić, V. i Cvitković, I. (2016) Vokativnost u hrvatskoj i srpskoj jezičnoj normi i upotrebi: morfološki pristup. Filološke studije, 14 (2), 228-242.

Kovačič, I. (1991) Subtitling and Contemporary Linguistic Theories. U Jovanovič, M. (ur.) Translation: A Creative Profession: Proceedings / XIIth World Congress of FIT - Belgrade. Beograd: Prevodilac, 407-417.

Lomheim, S. (1995) L'écriture sur l'écran: stratégies de sous-titrage à NRK, une étude de cas. Translatio, Nouvelles de la FIT/FIT Newsletter, 13(3-4), 288-293.

Lomheim, S. (1999) The Writing on the Screen. Subtitling: A Case Study from Norwegian Broadcasting (NRK), Oslo. U Anderman, G. i Rogers, M. (ur.) Word, Text, Translation: Liber Amicorum for Peter Newmark. Clevedon: Multilingual Matters, 190-207.

Luyken G. M., Herbst, T., Langham-Brown, J., Reid, H. i Spinhof, H. (1991) Overcoming Language Barriers in Television: Dubbing and Subtitling for the European Audience. Manchester: European Institute for the Media.

Mattsson, J. (2009) The Subtitling of Discourse Particles. A corpus-based study of well, you know, I mean, and like, and their Swedish translations in ten American films (Neobjavljeni doktorski rad). Švedska: Sveučilište u Gothenburgu.

Nida, E. A. i Taber, C. R. (1974) The theory and practice of translation. Leiden: Brill.

Nornes, A. M. (1999) For an Abusive Subtitling. Film Quarterly, 52 (3), 17-34.

Pavesi, M. (2005) La traduzione filmica: Aspetti del parlato doppiato dall'inglese allitaliano. Rim: Carocci.

Pavlović, N. (2002) The Pragmatic Theory of Politeness in TV Subtitling. Studia Romanica et Anglica Zagrabiensia, 47-48, 385-399.

Pedersen, J. (2017) The FAR model: assessing quality in interlingual subtitling. JoSTrans: The Journal of Specialised Translation, 28, 210-229.

Perego, E. (2005) La traduzione audiovisiva. Rim: Carocci.

Petillo, M. (2012) La traduzione audiovisiva nel terzo millennio. Milano: FrancoAngeli.

Silić, J. (2006) Funkcionalni stilovi hrvatskoga jezika. Zagreb: Disput.

Sokoli, S. (2007) Learning via Subtitling (LvS). A Tool for the Creation of Foreign Language Learning Activities based on Film Subtitling. U Carroll, M., Gerzymisch-Arbogast, H. i Nauert, S. (ur.) Multidimensional Translation: Audioviual Translation Scenarios. Saarbrücken: ATRC, 66-73. 
Williams, H. i Thorne, D. (2000) The value of teletext subtitling as a medium for language learning. System, 28(2), 217-228.

\title{
Filmografija
}

Sibilia, S. (2014) Smetto quando voglio (Mogu prestati kad god želim). Italija: Fandango, Ascent Film i RAI Cinema.

\section{Translation strategies in Croatian subtitles on the example of the Italian film Smetto quando voglio}

\author{
Andrea Rogošić \\ arogosic@ffst.hr \\ Faculty of Humanities and Social Sciences, University of Split \\ Petra Mrčela \\ pmrcela@gmail.com \\ Faculty of Humanities and Social Sciences, University of Split
}

\begin{abstract}
The aim of this paper is to quantify and describe the translation strategies applied in the subtitling of the Italian film Smetto quando voglio (2014) into Croatian. Due to the spatial and temporal constraints that operate in the process of subtitling, along with the diamesic shift from the spoken into the written language, the assumption is that reduction and neutralization strategies will be the most frequently applied strategies for the target text adaptation. Based on the transcription of the source text and Croatian subtitles, a quantitative analysis of translation strategies is performed, in accordance with Lomheim's model from 1999. Subsequently, the selected examples of the most frequently applied translation strategies, namely equivalent translation, omission, compression and neutralisation, are discussed. It is concluded that the application of reduction strategies does not impair the coherence of the target text, while the application of neutralisation changes the linguistic characterization of the film protagonists to a certain extent.

Key words: Croatian subtitles, reduction strategies, neutralisation
\end{abstract}

